\title{
Ethosome: a novel vesicular carrier for transdermal drug delivery
}

\author{
Saquib Raza Zahid ${ }^{1}$, Neeraj Upmanyu ${ }^{1}$, Surendra Dangi ${ }^{1 *}$, Sudhir Kumar Ray ${ }^{1}$, Prabhat Jain ${ }^{2}$, Geeta Parkhe ${ }^{2}$ \\ ${ }^{1}$ School of Pharmacy \& Research Peoples University, Bhopal (M.P.), India \\ ${ }^{2}$ Scan Research Laboratories, Bhopal (M.P.), India
}

\begin{abstract}
Delivery across skin is striking due to its easy convenience. However, drug delivery across skin is still a confront in biomedical sciences. Over the past few decades, various successful narrative devices and techniques have emerged to optimize drug delivery across skin whose barricading behaviour constricts entry of most of the therapeutic agents. Ethosomes are non-invasive delivery transporter that enables drugs to reach the deep skin layers and/or the systemic circulation. Although ethosomal systems are theoretically sophisticated, they are characterized by simplicity in their preparation, efficacy and safety. A combination that can highly inflate their application. Ethosomes are soft, malleable vesicles adapted for enhanced delivery of active agents. This article reviews work carried out method of preparation, application and characterization of ethosomal systems. Because of their exceptional structure, ethosomes are able to encapsulate and deliver through the skin highly lipophilic molecules such as testosterone, cannabinoids and minoxidil as well as cationic drugs such as trihexyphenidil and propranolol. Results obtained in a double-blind two-armed randomized clinical study showed that treatment with the ethosomal acyclovir formulation appreciably improved all the evaluated parameters. In further work, the ethosomal expertise was broadened to introduce agents into cultured cells and microorganisms. Enhanced delivery of bioactive molecules through the skin and cellular membranes by means of an ethosomal transporter opens numerous confronts and prospects for the research and future development of novel improved therapies.
\end{abstract}

Keywords: Ethosomes, Skin layers, Characterization

Article Info: Received 30 Sep, 2018; Review Completed 29 Oct 2018; Accepted 31 Oct 2018; Available online 15 Nov 2018

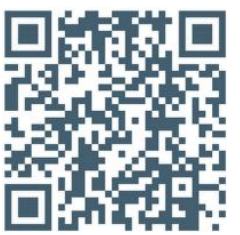

Cite this article as:

Zahid SR, Upmanyu N, Dangi S, Ray SK, Jain P, Parkhe G, Ethosome: a novel vesicular carrier for transdermal drug delivery, Journal of Drug Delivery and Therapeutics. 2018; 8(6): 318-326

DOI: http://dx.doi.org/10.22270/jddt.v8i6.2028

Surendra Dangi, School of Pharmacy \& Research, Peoples University, Bhopal (M.P.)

\section{INTRODUCTION}

The impending benefits related to transdermal drug delivery are widely reported in the literature 1,2 . Among these advantages are compact side effects and prevention of first-pass hepatic elimination and intestinal degradation. However, percutaneous delivery of most molecules is often excluded because of the barrier nature of the skin, which functionally impedes the entrance of exogenous materials. To overcome this obstruction, various methods of skin permeation enhancement described in numerous scientific works and patents have been used ${ }^{3}, 4$. Human skin has a multifunctional role including its major role as a barrier against both the outlet of endogenous substances (water) and the entrance of xenobiotic material (chemicals and drugs). It is regarded as first line of protection in human body. The stratum corneum consisting corneocytes mainly accounts for the barrier properties of skin ${ }^{5,6}$. From some time several aspect have come out which has given immense esteem and rapid progress to transdermal delivery formulations over conventional formulations because circumvention of variations which appear at gastro-intestinal absorption 7, improvement in bioavailability of drugs by delivering the active principles directly into the systemic circulation, bypassing the hepatic metabolism ${ }^{8}$, by giving a constant, controlled drug enter decreasing the variations in drug plasma levels 9, augmentation in patient compliance by providing a simplified way of administration, lowest risk of trauma or any other injury of tissue. In order to increase the permeability of the skin for transdermal delivery of drugs several passive as well as active procedure have been proposed such as penetration enhancers, vesicles, iontophoresis, supersaturated systems, electroporation, phonophoresis, use of microneedles and jet injectors, etc. Although all the efforts devoted to penetration enhancement, only few bioactive agents are currently transdermally administered. One of the most utilizable methods for drugs' transport across the skin is the use of 
vesicle formulation as skin delivery systems. Ethosomes are soft, malleable lipid vesicles composed mainly of phospholipids, alcohol in relatively high concentration (20$45 \%$ ) and water (Fig. 1). Ethosomes were first developed by Touitou and her colleagues in 1997 10-12. This transporter presents interesting features correlated with its ability to permeate whole through the human skin due to its high deformability. The physicochemical characteristics of ethosomes allow these vesicular phospholipids as the vesicle forming component of ethosomal system. Phospholipids with various chemical structures like phosphatidyl choline, phosphatidyl ethanolamine are used at concentrations ranging from 0.5 $10 \%$.

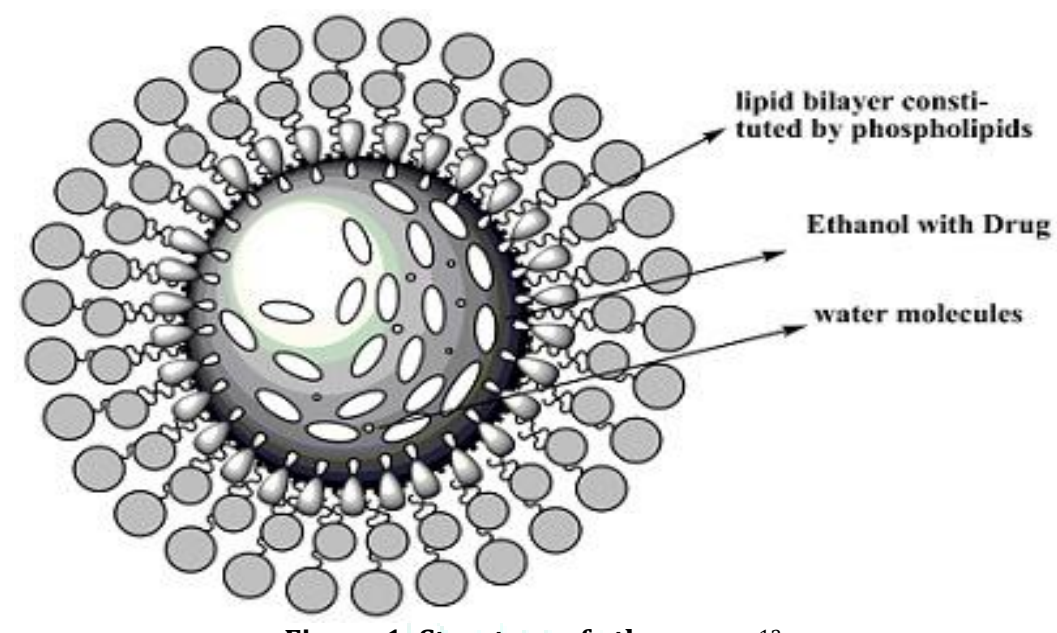

Figure 1: Structure of ethosomes ${ }^{13}$

\section{Structure of skin}

Stratum corneum is the remotest layer of the epidermis. It consists of 10 to 25 layers of dead, elongated, fully keratinized corneocytes, which are fixed in a matrix of lipid bilayers. It has been exposed that the stratum corneum is the main barrier to penetration through the skin. When a topical formulation is placed on the skin, the active drug is required to penetrate through the stratum corneum into the viable tissue (Fig 2). The limiting factor for these processes is the slow diffusion through the dead horny layer of skin. Stratum corneum behaves as a hydrophobic membrane. The rates of permeation of skin by low and high molecular weight organic non electrolytes are mostly determined within the stratum corneum 14,15 .

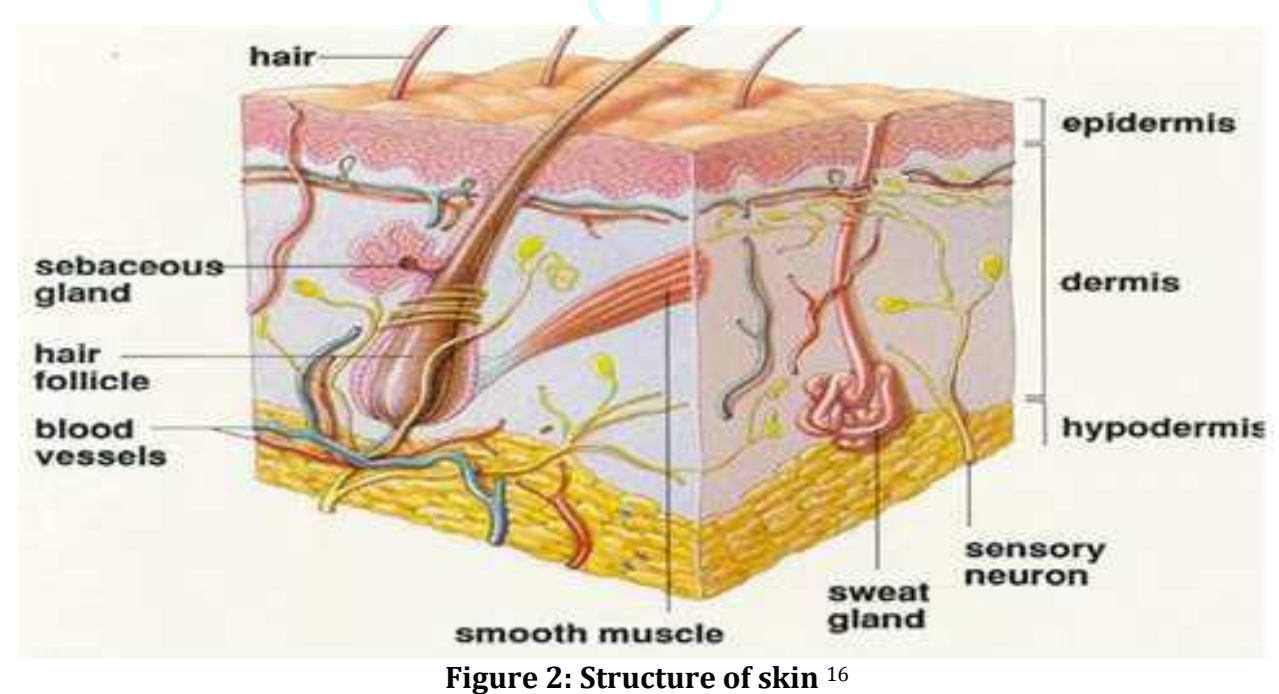

\section{COMPOSITION OF ETHOSOMES}

Ethosomes exhibit lipid bilayer like liposomes; however they differ from liposomes in terms of composition (high content of ethanol). The ethosomes are composed of hydroalcoholic or hydro/glycolicphospholipid in which the concentration of alcohol is relatively high. Ethosomes may contain phospholipids with various chemical structures like phosphatidylcholine, phosphatidic acid, phosphatidylserine, Phosphatidyl ethanolamine, phosphatidyl glycerol, phosphatidyl inositol, alcohol (ethanol or isopropyl alcohol), water and propylene glycol (or other glycols). Some preferred phospholipids such as
Phospholipon 90 (PL-90). It is usually employed in a range of $0.5-10 \% \mathrm{w} / \mathrm{w}$. Cholesterol at concentrations ranging between $0.1-1 \%$ can also be added to the preparation. Alcohol, such ethanol and isopropyl alcohol; among glycols, propylene glycol and Transcutol are generally used which may range from 20 to $50 \%$ in the final product. In addition to non-ionic surfactants (PEG-alkyl ethers) and cationic lipids (cocoamide, POE alkyl amines, dodecylamine, cetrimide etc) can be combined with the phospholipids in the preparations ${ }^{17}$. The concentration of the non-aqueous phase (alcohol and glycol combination) may range between 22 to $70 \%$. Various additives which are used for formulation of ethosomes are listed in the Table 1. 
Table 1: Different additive employed in formulation of ethosomes 18-22

\begin{tabular}{|l|l|l|}
\hline \multicolumn{1}{|c|}{ Class } & \multicolumn{1}{|c|}{ Example } & \multicolumn{1}{c|}{ Uses } \\
\hline Phospholipids & $\begin{array}{l}\text { Soya phosphatidyl choline } \\
\text { Egg phosphatidyl choline } \\
\text { Dipalmityl phosphatidyl choline } \\
\text { Distearyl phosphatidyl choline }\end{array}$ & $\begin{array}{l}\text { It influences on the size,entrapment efficacy, zeta } \\
\text { potential and penetration properties of the } \\
\text { vesicles. }\end{array}$ \\
\hline Alcohol & $\begin{array}{l}\text { Ethanol } \\
\text { Isopropyl alcohol }\end{array}$ & $\begin{array}{l}\text { For providing the softness for vesicle membrane } \\
\text { As a penetration enhancer }\end{array}$ \\
\hline Polyglycol & Propylene glycol, Transcutol RTM & As a skin penetration enhancer \\
\hline Cholesterol & Cholesterol & For providing the stability to vesicle membrane \\
\hline Edge activators & N-DMSO ,Tween[22], Span & Enhances skin permeability \\
\hline Dye & $\begin{array}{l}\text { Rhodamine-123 } \\
\text { Rhodamine red Fluorescene } \\
\text { Isothiocynate(FITC) } \\
\text { 6- Carboxy fluorescence }\end{array}$ & For characterization study \\
\hline others & Dicetyl phosphate & Prevent aggregation of vesicles \\
\hline Vehicle & Carbopol D-934, HPMC & As a gel former \\
\hline
\end{tabular}

\section{Advantage of ethosomal drug delivery system}

In comparison to other transdermal \& dermal delivery systems, Ethosomal drug delivery systems contain several advantages. Few advantages are;

1. It contains non-toxic raw material in formulation.

2. Delivery of large molecules (peptides, protein molecules) is possible.

3. Enhanced permeation of drug through skin for transdermal drug delivery.

4. High patient compliance: The ethosomal drug is administrated in semisolid form (gel or cream) hence producing high patient compliance.

5. Simple method for drug delivery in comparison to Iontophoresis and Phonophoresis and other complicated methods.

6. Ethosomal drug delivery system can be applied widely in Pharmaceutical, Veterinary, Cosmetic fields.

7. Ethosomal system acts as delivery system for a fluorescent probe (quantum dots) to the skin, in terms of quantity and depth.

8. Ethosomes show highest transdermal flux enhances the permeation of drug through deeper layers of skin.

9. Due to intense research toxicological profiles of the ethosome components are well-evaluated and documented in the scientific literature thus the ethosome technology has no large-scale drug development risk

10. The ethosomal system is passive, non-invasive and is available for immediate commercialization

11. Drugs entrapped in ethosome having different physicchemical characteristics and olecular sizes are showing high degree of permeation compare to other nano-carriers.

12. Ethosomes improve skin delivery under occlusive and non-occlusive conditions.

13. High market attractiveness for products with proprietary technology. Relatively simple to manufacture with no complicated technical investments required for production of Ethosomes ${ }^{23}$.

\section{Disadvantages of ethosomal drug delivery}

1. Ethosomes with poor shells may clump together and leads to precipitation.

2. Adequate solubility of the drug in both lipophilic and aqueous environments to reach dermal microcirculation and gain access to the systemic circulation.
3. Skin irritation or dermatitis due to excipients and enhancers of drug delivery systems.

4. Ethosomal administration is not a means to achieve rapid bolus type drug input, rather it usually designed to offer slow, sustained drug delivery.

5. Drugs that require high blood levels cannot be administered -limited to only potent drugs (daily dose $-10 \mathrm{mg}$ or less)

6. Poor practical yield.

7. Transfer of ethosomes from organic to aqueous layer leads to loss of product

8. The molecular size of the drug should be reasonable that it should be absorbed percutaneously.

9. Adhesive may not adhere well to all types of skin.

10. May not be economical.

11. In case if shell locking is ineffective then the ethosomes may coalescence and fall apart on transfer into water ${ }^{24-29}$.

\section{MECHANISM OF DRUG PENETRATION}

The mechanism of penetration of the ethosomes involves two concurrent mechanisms of ethanol effect and ethosome effect on the stratum corneum lipid bilayer Because of the use of ethanol in the preparation of the ethosomes, the deformability of the vesicles is increased. The high alcohol content is expected to partially extract the stratum corneum lipids (Fig 3).These processes are responsible for increasing inter and intracellular permeability of ethosomes. The ultra deformable vesicles can move in the path of the disordered stratum corneum and finally release drug in the deeper layers of the skin 30 .

\section{$\checkmark \quad$ Ethosomes effect \\ $\checkmark \quad$ Ethanol effect}

\section{Ethosomes effect}

Increased cell membrane lipid fluidity caused by the ethanol of ethosomes results increased skin permeability. So the ethosomes permeates very easily inside the deep skin layers, where it got fused with skin lipids and releases the drugs into deep layer of skin

\section{Ethanol effect}

Ethanol acts as a penetration enhancer through the skin. The mechanism of its penetration enhancing effect is well known. Ethanol penetrates into intercellular lipids and increases the fluidity of cell membrane lipids and decrease the density of lipid multilayer of cell membrane 31 . 


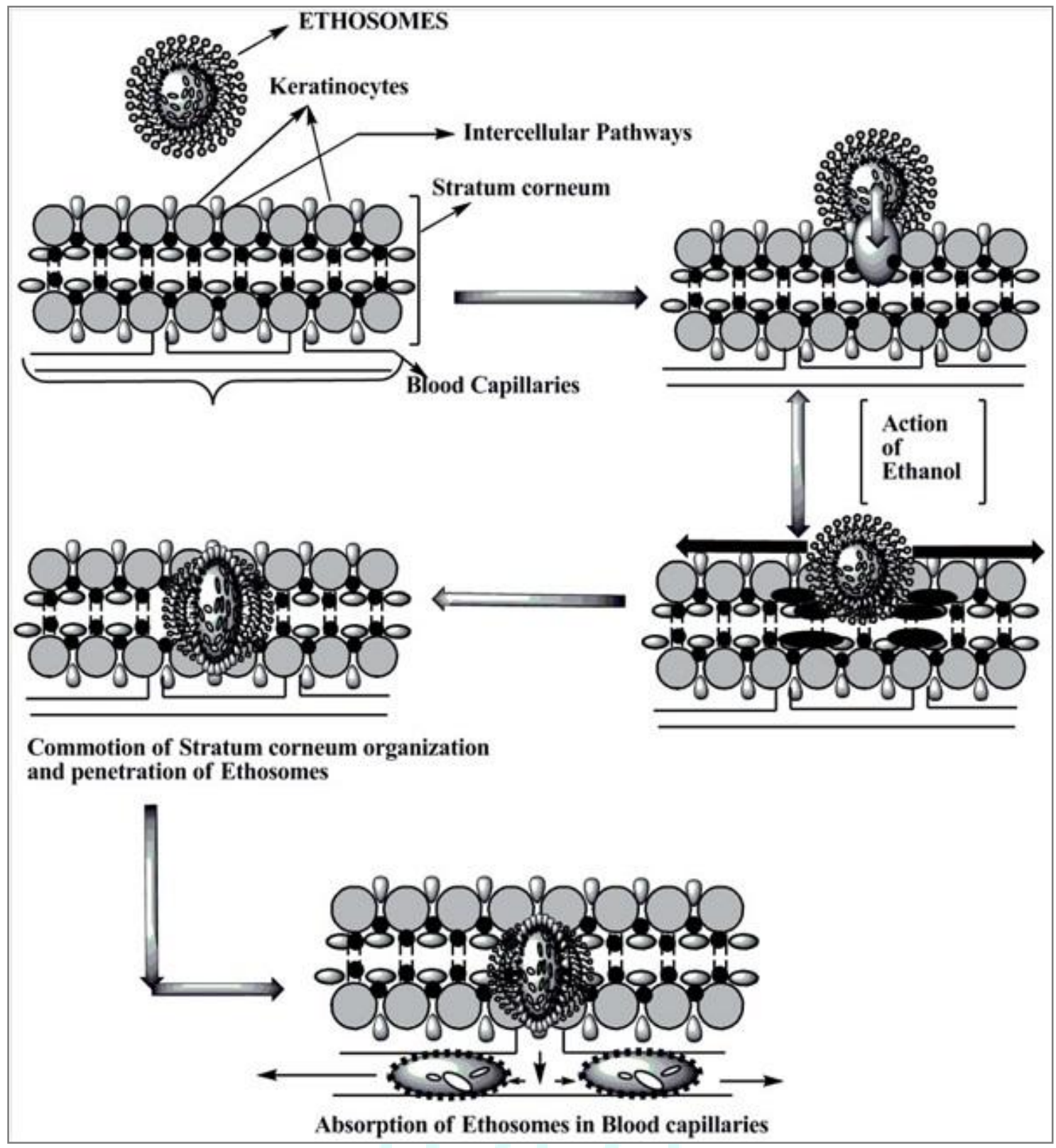

Figure 3: Mechanism of action of ethosomes for skin delivery 13

\section{METHODS OF PREPARATION}

Ethosomes can be prepared and formulated by four methods. All methods are sound simple and convenient because no need of complex processes or sophisticated instruments.

\section{Cold method}

This is the most common method utilized for the preparation of ethosomal formulation. In this method phospholipid, drug and other lipid materials are dissolved in ethanol in a covered vessel at room temperature by vigorous stirring with the use of mixer. Propylene glycol or other polyol is added during stirring. This mixture is heated to $300 \mathrm{C}$ in a water bath. The water heated to $300 \mathrm{C}$ in a separate vessel is added to the mixture, which is then stirred for $5 \mathrm{~min}$ in a covered vessel. The vesicle size of ethosomal formulation can be decreased to desire extend using sonication 32 or extrusion 33 method. Finally, the formulation is stored under refrigeration ${ }^{34}$.
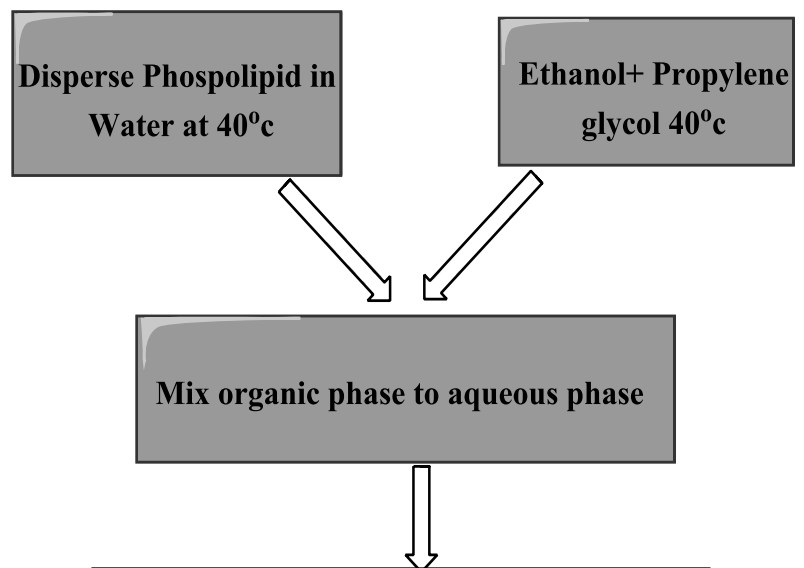

Add drug dissolved in suitable solvent (Water or Ethanol depending on solubility) 


\section{Hot method}

In this method phospholipid is dispersed in water by heating in a water bath at $400 \mathrm{C}$ until a colloidal solution is obtained. In a separate vessel ethanol and propylene glycol are mixed and heated to $400 \mathrm{C}$. Once both mixtures reach $400 \mathrm{C}$, the organic phase is added to the aqueous one. The drug is dissolved in water or ethanol depending on its hydrophilic/ hydrophobic properties. The vesicle size of ethosomal formulation can be decreased to the desire extent using probe sonication or extrusion method 35 .

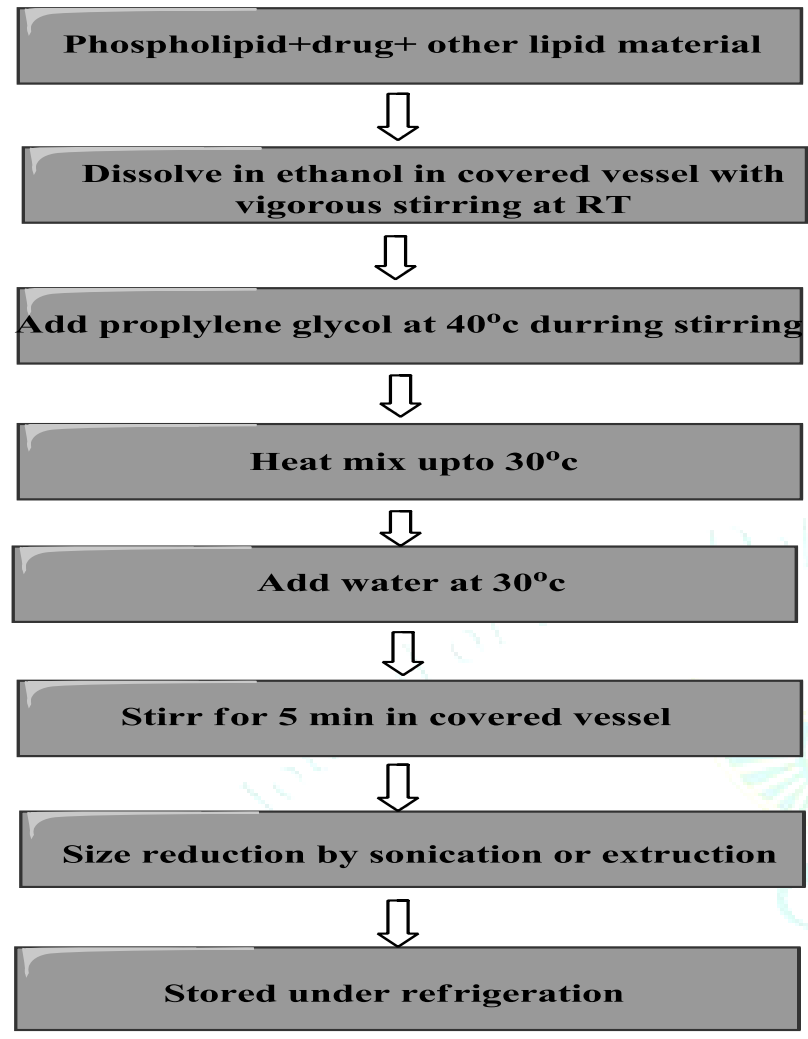

\section{Classic method}

The phospholipid and drug are dissolved in ethanol and heated to $30^{\circ} \mathrm{C} \pm 1^{\circ} \mathrm{C}$ in a water bath. Double distilled water is added in a fine stream to the lipid mixture, with constant stirring at 700rpm, in a closed vessel. The resulting vesicle suspension is homogenized by passing through a polycarbonate membrane using a hand extruder for three cycles ${ }^{36}$.

\section{Mechanical dispersion method}

Soya phosphotidylcholine is dissolved in a mixture of chloroform: methanol in round bottom flask (RBF). The organic solvents are removed using rotary vacuum evaporator above lipid transition temperature to form a thin lipid film on wall of the RBF. Finally, traces of solvent mixture are removed from the deposited lipid film by leaving the contents under vacuum overnight. Hydration is done with different concentration of hydroethanolic mixture containing drug by rotating the RBF at suitable temperature ${ }^{36}$.

\section{CHARACTERIZATION OF ETHOSOMES ${ }^{37}$}

\section{Vesicle size and Zeta potential}

Particle size and zeta potential can be determined by dynamic light scattering (DLS) using a computerized inspection system and photon correlation spectroscopy (PCS).

\section{Vesicle shape}

Visualization of ethosomes can be done using transmission electron microscopy (TEM) and by scanning electron microscopy (SEM). Visualization by electron microscopy reveals a thosomal formulation exhibited vesicular structure $300-400 \mathrm{~nm}$ in diameter. The vesicles seem to be alleable as evident by their imperfect round shape.

\section{Entrapment efficiency}

The entrapment efficiency of drug in ethosomes can be measured by the ultracentrifugation technique. The chemical nature of the lipid is an important factor in determining the EE of drug in the ethosomes because lipid which forms bilayer structure holds the drug perfectly. On the other hand, the imperfection of the lipid structure could offer space to accommodate the drug. The vesicles are separated in a high speed cooling centrifuge at 20,000 rpm for 90 minutes in the temperature maintained at $4^{\circ} \mathrm{C}$. Separate the sediment and supernatant liquids determine the amount of drug in the sediment by lysing the vesicles using methanol.

$\%$ Entrapment = Actual content $/$ Theoretical content $\mathrm{x} 100$

\section{Surface tension measurement}

The surface tension activity of drug in aqueous solution can be measured by the ring method in a Du Nouy ring tensiometer.

\section{Surface morphology study}

Different types of lipids influence the surface morphology or shape of the particles. Lipid microparticle suspensions were deposited on metallic stubs then placed in liquid nitrogen and dried under vacuum. The freeze-dried microparticles were coated uniformly with gold. It is characterized for morphology and surface properties using a scanning electron microscope.

\section{Drug content}

Drug content of the ethosomes can be determined using UV spectrophotometer. This can also be quantified by a modified high performance liquid chromatographic method.

\section{Transition temperature}

The Transition temperature ( $\mathrm{T}$ ) of vesicular lipids is measured in duplicate by DSC in an aluminum pan at a heating rate of $10^{\circ} \mathrm{C}$ per min within a temperature range from $20^{\circ}-300^{\circ} \mathrm{C}$., under a constant nitrogen stream

\section{Stability studies}

The ability of ethosomal preparations to retain the drug (i.e., drug-retentive behavior) can be checked by keeping the preparations at different temperatures, i.e., $25 \pm 2^{\circ} \mathrm{C}$ (room temperature, RT), $37 \pm 2^{\circ} \mathrm{C}$ and $45 \pm 2^{\circ} \mathrm{C}$ for different periods of time $(1,20,40,60,80$ and 120 days). The ethosomal preparations were kept in sealed vials $(10 \mathrm{ml}$ capacity) after flushing with nitrogen. The stability of ethosomes was also determined quantitatively by monitoring size and morphology of the vesicles using DLS and TEM.

\section{Degree of deformability and turbidity}

The degree of deformability of the Ethosomal preparation can be performed by extrusion method and the turbidity of the preparation can be performed by using nephelometer 


\section{Skin permeation studies}

Confocal laser scanning microscopy (CLSM) method is used to determine the depth of penetration from Ethosomes. The ethosomes shows significantly higher skin deposition possibly due to combined effect of ethanol and phospholipid thus providing a mode for dermal and transdermal delivery.

\section{In vitro drug release study and Drug deposition study}

In vitro drug release study and drug deposition of ethosomal preparation can be performed by Franz diffusion cell with artificial or biological membrane, Dialysis bag diffusion.

\section{Phospholipid-ethanol interaction}

The Phospholipid-ethanol interaction was studied by using Proton decoupled 31P-NMR and Differential Scanning calorimetry.

\section{EVALUATION OF ETHOSOME 38}

\section{Vesicle-skin interaction study by TEM and SEM}

From animals ultra-thin sections were cut (Ultracut, Vienna, Austria), collected on formvar coated grids and examined under transmission electron microscope. For SEM analysis, the sections of skin after dehydration were mounted on stubs using an adhesive tape and were coated with gold palladium alloy using a fine coat ion sputter coater. The sections were examined under scanning electron microscope.

Filter membrane-vesicle interaction study by scanning electron microscopy

Vesicle suspension $(0.2 \mathrm{~mL})$ was applied to filter membrane having a pore size of $50 \mathrm{~nm}$ and placed in diffusion cells. The upper side of the filter was exposed to the air, whereas the lower side was in contact with PBS (phosphate buffer saline solution), ( $\mathrm{pH}$ 6.5). The filters were removed after 1 hour and prepared for SEM studies by fixation at $4^{\circ} \mathrm{C}$ in Karnovsky's fixative overnight followed by dehydration with graded ethanol solutions (30\%, 50\%, 70\%, 90\%, 95\%, and $100 \% \mathrm{vol} / \mathrm{vol}$ in water). Finally, filters were coated with gold and examined in SEM.

Vesicle-skin interaction study by fluorescence microscopy

Fluorescence microscopy was carried according to the protocol used for TEM and SEM study. Paraffin blocks are used, were made, $5-\mu \mathrm{m}$ thick sections were cut using microtome (Erma optical works, Tokyo, Japan) and examined under a fluorescence micro Cytotoxicity Assay MT-2 cells (Tlymphoid cell lines) were propagated in
Dulbecco's modified Eagle medium (HIMEDIA, Mumbai, India) containing $10 \%$ fetal calf serum, $100 \mathrm{U} / \mathrm{mL}$ penicillin, $100 \mathrm{mg} / \mathrm{mL}$ streptomycin, and $2 \mathrm{mmol} / \mathrm{L}$ Lglutamine at $37^{\circ} \mathrm{C}$ under a $5 \% \quad \mathrm{CO} 2$ atmosphere. Cytotoxicity was expressed as the cytotoxic dose 50 (CD50) that induced a $50 \%$ reduction of absorbance at $540 \mathrm{~nm}$.

\section{Skin permeation studies}

The hair of test animals (rats) were carefully trimmed short $(<2 \mathrm{~mm})$ with a pair of scissors, and the abdominal skin was separated from the underlying connective tissue with a scalpel. The excised skin was placed on aluminums foil, and the dermal side of the skin was gently teased off for any adhering fat and/or subcutaneous tissue. The effective permeation area of the diffusion cell and receptor cell volume was $1.0 \mathrm{~cm} 2$ and $10 \mathrm{~mL}$, respectively. The temperature was maintained at $32^{\circ} \mathrm{C} \pm 1^{\circ} \mathrm{C}$. The receptor compartment contained phosphate buffer saline solution $(10 \mathrm{~mL}$ of $\mathrm{pH}$ 6.5). Excised skin was mounted between the donor and the receptor compartment. Ethosomal formulation $(1.0 \mathrm{~mL})$ was applied to the epidermal surface of skin. Samples $(0.5 \mathrm{~mL})$ were withdrawn through the sampling port of the diffusion cell at $1,2,4,8,12,16,20$ \& 24 hour time intervals and analyzed by high performance liquid chromatography assay.

\section{HPLC Assay}

The amount of drug permeated in the receptor compartment during in vitro skin permeation experiments and in MT-2 cell was determined by HPLC assay.

\section{Drug uptake studies}

The uptake of drug into MT- 2 cells $(1 \times 106$ cells $/ \mathrm{mL})$ was performed in 24-well plates (Corning Inc) in which $100 \mu \mathrm{L}$ RPMI medium was added. Cells were incubated with 100 $\mu \mathrm{L}$ of the drug solution in phosphate buffer saline solution ( $\mathrm{pH}$ 7.4), ethosomal formulation, or marketed formulation, and then drug uptake was determined by analyzing the drug content by HPLC assay.

\section{Statistical analysis}

Statistical significance of all the data generated was tested by employing ANOVA followed by studentized range test. A confidence limit of $\mathrm{P}<.05$ was fixed for interpretation of the results using the software PRISM (GraphPad, Version 2.01, San Diego, CA).

\section{APPLICATION OF ETHOSOMES}

Ethosomes find its diverse applications in various categories of drugs like Antifungal, Antibiotics, Skin infections and Cosmetic field. Some are listed as below (Table 2).

Table 2 Applications of ethosomes 39,40

\begin{tabular}{|l|l|l|l|}
\hline $\begin{array}{l}\text { Principle } \\
\text { ingredients }\end{array}$ & Formulation & Rationale of ethosomal delivery & Application \\
\hline $\begin{array}{l}\text { 5-aminolevulivic } \\
\text { acid(ALA) }\end{array}$ & $\begin{array}{l}\text { 5-aminolevulivic } \\
\text { Acid ethosomes }\end{array}$ & $\begin{array}{l}\text { Significantly improved the delivery of ALA in the } \\
\text { inflammatory skin. }\end{array}$ & Anti- psoriasis \\
\hline Erythromycin & $\begin{array}{l}\text { Erythromycin } \\
\text { ethosomes }\end{array}$ & $\begin{array}{l}\text { Ethosomal erythromycin was highly efficient in } \\
\text { eradicating S. aureus- induced intradermal infections }\end{array}$ & Anti bacterial \\
\hline Isoeugenol & $\begin{array}{l}\text { Isoeugenol } \\
\text { ethosomes }\end{array}$ & $\begin{array}{l}\text { Chemicals (allergen) in vesicular carrier system can } \\
\text { enhance the sensitizing capacity. }\end{array}$ & allergen \\
\hline Matrine & Matrine ethosomes & Improves the percutaneous permeation & Anti- inflammatory \\
\hline Methotrexate & $\begin{array}{l}\text { Methotrexate } \\
\text { ethosomes }\end{array}$ & $\begin{array}{l}\text { Ethosomes showed favourable skin permeation } \\
\text { characteristic }\end{array}$ & Anticancer \\
\hline Minoxidil & Minoxidil ethosomes & $\begin{array}{l}\text { Enhance the penetration and accumulation of minoxidil } \\
\text { in the skin by Pilosebaceous targeting }\end{array}$ & $\begin{array}{l}\text { Hair growth } \\
\text { promoter }\end{array}$ \\
\hline
\end{tabular}




\begin{tabular}{|c|c|c|c|}
\hline Testosterone & $\begin{array}{l}\text { Testosterone } \\
\text { ethosomes }\end{array}$ & $\begin{array}{l}\text { Testosterone ethosome for Enhanced transdermal } \\
\text { delivery }\end{array}$ & Steroid hormone \\
\hline $\begin{array}{l}\text { Trihexyphenidyl } \\
\text { HCL }\end{array}$ & $\begin{array}{l}\text { Trihexyphenidyl HCL } \\
\text { ethosomes }\end{array}$ & $\begin{array}{l}\text { Increased drug entrapment efficiency, reduced side } \\
\text { effect and constant systemic levels }\end{array}$ & Anti-parkinsonian \\
\hline Acyclovir & Acyclovir ethosomes & $\begin{array}{l}\text { Binary combination of the Lipophilic drug ACV-C16 and } \\
\text { the ethosomes enhanced ACV absorption into } \\
\text { synergistically the skin }\end{array}$ & Anti-viral \\
\hline Azelaic acid & $\begin{array}{l}\text { Azelaic acid } \\
\text { ethosomes }\end{array}$ & $\begin{array}{l}\text { Release rate was higher from ethosomes than from } \\
\text { liposomes }\end{array}$ & Anti- keratinizing \\
\hline Bacitracin & Bacitracin ethosomes & $\begin{array}{l}\text { Ethosomal enhances intracellular delivery of and } \\
\text { reduced drug toxicity in the skin }\end{array}$ & $\begin{array}{l}\text { Polypeptide } \\
\text { antibacterial }\end{array}$ \\
\hline Colchicine & Colchicine ethosomes & $\begin{array}{l}\text { Enhance skin accumulation, prolong release and } \\
\text { improve the specificity }\end{array}$ & Anti-gout \\
\hline Finasteride & $\begin{array}{l}\text { Finasteride } \\
\text { ethosomes }\end{array}$ & $\begin{array}{l}\text { Enhanced percutaneous absorption of finasteride 5-a } \\
\text { reductase inhibitor }\end{array}$ & Anti-Fungal \\
\hline Fluconazole & $\begin{array}{l}\text { Fluconazole } \\
\text { ethosomes }\end{array}$ & enhances the skin permeation & Anti-Fungal \\
\hline Ibuprofen & Ibuprofen ethosomes & $\begin{array}{l}\text { Transdermal nanosystem, designed by using an } \\
\text { ethosomal carrier }\end{array}$ & Antipyretic \\
\hline Ligustrazine & $\begin{array}{l}\begin{array}{l}\text { Ligustrazine } \\
\text { ethosomes }\end{array} \\
\end{array}$ & Ethosome patch enhances the permeation the skin & $\begin{array}{l}\text { Pulmonary } \\
\text { vasodilator }\end{array}$ \\
\hline Salbutamol & $\begin{array}{l}\text { Salbutamol } \\
\text { ethosomes }\end{array}$ & Enhanced drug delivery through skin with ethosomes & Anti-asthmatic \\
\hline Sotalol & Sotalol ethosomes & Enhances the systemic absorption & anti-arrtthmic \\
\hline Vitamin A, C, E & $\begin{array}{l}\text { Vitamin A C,E } \\
\text { ethosomes }\end{array}$ & $\begin{array}{l}\text { Anti-oxidation of phospholipid was increase due to the } \\
\text { synergistic interaction of all three together as compare } \\
\text { to individual use }\end{array}$ & Vitamin \\
\hline Stavudine & Stavudine ethosomes & $\begin{array}{l}\text { Ethosome increase the transdermal flux, prolong the } \\
\text { release of Stavudine }\end{array}$ & Antiretroviral ${ }^{40}$ \\
\hline
\end{tabular}

\section{Marketed product of ethosomes 41,42}

In 2000, the ethosomes technology began to Commercialize. There are many companies which developed ethosomes products (Table 3).

Table 3: Marketed formulations of ethosomes

\begin{tabular}{|l|l|l|}
\hline Name of product & \multicolumn{1}{|c|}{ Uses } & \multicolumn{1}{|c|}{ Manufacturer } \\
\hline Cellutight EF & $\begin{array}{l}\text { Topical cellulite cream, contains a powerful combination of } \\
\text { ingredients to increase metabolism and break down fat }\end{array}$ & Hampden Health, USA \\
\hline Decorin cream & $\begin{array}{l}\text { Anti-aging cream treating, repairing the visible } \\
\text { aging signs of the skin including wrinkle lines, sagging, age } \\
\text { spots, loss of elasticity, and hyper pigmentation }\end{array}$ & $\begin{array}{l}\text { Genome Cosmetics, } \\
\text { Pennsylvania, US }\end{array}$ \\
\hline Nanominox & $\begin{array}{l}\text { First minoxidil containing product, which uses ethosomes. } \\
\text { Contains 4\% Minoxidil, well-known hair growth promoter } \\
\text { that must be metabolized by sulfation to the active } \\
\text { compound. }\end{array}$ & Sinere, Germany \\
\hline Noicellex & Topical anti-cellulite cream & Novel Therapeutic Technologies, Israel \\
\hline Skin genuity & Powerful cellulite buster reduces orange peel & Physonics Nottingham, UK \\
\hline Supravir cream & For the treatment of herpes virus & Trima,Israel \\
\hline Body Shape & $\begin{array}{l}\text { Gel executive solidification cellulite education, stretching the } \\
\text { skin flexible and based on a technology called ethosomes }\end{array}$ & Maccabi CARE \\
\hline
\end{tabular}

\section{Future perspective}

For transdermal delivery of drugs, stratum corneum is the main barrier layer for penetration of drug. Various methods have been discovered to enhanced skin penetration of drugs lipid vehicle based enhancement approach has drawn considerable interest in recent past. Studies will continue further to improve skin delivery of drug using lipid vesicles. Introduction of ethosomes has initiated a new area in vesicular research for transdermal drug delivery. Different reports show a promising future of ethosomes in making transdermal delivery of various agents more effective. Further, research in this area will allow better control over drug release in vivo, allowing physician to make the therapy more effective. Ethosomes offers a good opportunity for the non-invasive delivery of small, medium and large sized drug molecules. The results of the first clinical study of acyclovir-ethosomal formulation support this conclusion. Multiliter quantities of ethosomal formulation can be prepared very easily. It, therefore, should be not before long that the corresponding drug formulation would have found their way into clinics to be tested for widespread usage. Thus, it can be a logical conclusion that ethosomal formulations possess promising future in effective dermal/transdermal delivery of bioactive agents.

\section{Patented}

Ethosome was invented and patented by Prof. Elka Touitou along with her students of Department of Pharmaceutics at the Hebrew University School of Pharmacy 43, 44. 
Novel Therapeutic Technologies Inc (NTT) of Hebrew University has been succeeded in bringing a number of products to the market based on ethosome delivery system Table 4.

Table 4: Patents claimed for ethosome formulations 45

\begin{tabular}{|c|c|c|c|c|}
\hline Title & Inventor & Patent no & Year & Results \\
\hline $\begin{array}{l}\text { Tretinoin ethosomes gel and } \\
\text { preparation method thereof }\end{array}$ & $\begin{array}{l}\text { Hu Chunmei, Liu Yan, } \\
\text { Wang Jing, Li Rong }\end{array}$ & $\begin{array}{l}\text { CN104983675 } \\
\text { A }\end{array}$ & 2015 & $\begin{array}{l}\text { the prepared tretinoin ethosomes } \\
\text { gel is an externally-used } \\
\text { transdermal delivery preparation }\end{array}$ \\
\hline $\begin{array}{l}\text { Chinese medicinal ethosome } \\
\text { gel patch for treating herpes } \\
\text { zoster and preparation } \\
\text { method }\end{array}$ & $\begin{array}{l}\text { Bu Ping; Hu Rong; Chen } \\
\text { Lin; Wei Rong; Wu } \\
\text { Huanhuan; Huang Xiaoli }\end{array}$ & $\begin{array}{l}\text { CN103536700 } \\
\text { (A) }\end{array}$ & 2014 & $\begin{array}{l}\text { Easy in medication and convenient } \\
\text { to use, has a good therapeutic effect, } \\
\text { quick response, }\end{array}$ \\
\hline $\begin{array}{l}\text { Ethosome gel film-coating } \\
\text { agent with multiple wound } \\
\text { repair effects and preparation } \\
\text { method of ethosome gel film- } \\
\text { coating agent } 1\end{array}$ & $\begin{array}{l}\text { Chen Jie; Huang } \\
\text { Changping; Zheng } \\
\text { Maoxin; Nie Kaipin }\end{array}$ & $\begin{array}{l}\text { CN103893394 } \\
\text { (A) }\end{array}$ & 2014 & $\begin{array}{l}\text { The Ethosome entrapped film- } \\
\text { coating agent helps to promote } \\
\text { healing and nutrition supplying of } \\
\text { the wound tissue. }\end{array}$ \\
\hline $\begin{array}{l}\text { Daptomycin ethosome } \\
\text { preparation }\end{array}$ & $\begin{array}{l}\text { Li Chong; Liu Xia; Yin } \\
\text { Qikun; Wang Xiaoying; } \\
\text { Chen Zhangbao }\end{array}$ & $\begin{array}{l}\text { CN103006562 } \\
\text { (A) }\end{array}$ & 2013 & $\begin{array}{l}\text { It is excellent in transdermal } \\
\text { performance, drug release and has } \\
\text { certain slow-release effect, and the } \\
\text { preparation method is simple and } \\
\text { convenient, low in cost and good in } \\
\text { stability }\end{array}$ \\
\hline $\begin{array}{l}\text { Ethosome preparation of male } \\
\text { hormone }\end{array}$ & $\begin{array}{l}\text { Shu Meng; Jianxin Li; } \\
\text { Yanmin Guan; }\end{array}$ & $\begin{array}{l}\text { CN102406605 } \\
\text { (A) }\end{array}$ & 2012 & $\begin{array}{l}\text { To improve transdermal transport } \\
\text { of male hormone }\end{array}$ \\
\hline $\begin{array}{l}\text { Paclitaxel ethosome gel and } \\
\text { preparation method there of }\end{array}$ & $\begin{array}{l}\text { Jianping Tan; Lixin } \\
\text { Jiang; Tanran Chang; } \\
\text { Zhiwen Zhou }\end{array}$ & $\begin{array}{l}\text { CN102579323 } \\
\text { (A) }\end{array}$ & 2012 & $\begin{array}{l}\text { The action of stimulation to the skin } \\
\text { can be reduced, and the } \\
\text { percutaneous permeation effect is } \\
\text { good. }\end{array}$ \\
\hline $\begin{array}{l}\text { Acyclovir ethosome and } \\
\text { preparation method there of } \\
21\end{array}$ & Xuewen Wu; Yan Xiong & $\begin{array}{l}\text { CN102133183 } \\
\text { (A) }\end{array}$ & 2011 & $\begin{array}{l}\text { Acyclovir ethosome has high } \\
\text { stability and narrow particle size } \\
\text { distribution }\end{array}$ \\
\hline $\begin{array}{l}\text { Podophyllotoxin ethosomes } \\
\text { and preparation methods } \\
\text { there of } 22\end{array}$ & $\begin{array}{l}\text { Nianping Feng; Yanyan } \\
\text { Yu; Jihui Zhao; Haiting } \\
\text { Weng; Xiaoqin Shi }\end{array}$ & $\begin{array}{l}\text { CN102144972 } \\
\text { (A) }\end{array}$ & 2011 & $\begin{array}{l}\text { The invention discloses two } \\
\text { preparation methods for the } \\
\text { podophyllotoxin ethosomes }\end{array}$ \\
\hline $\begin{array}{l}\text { Terbinafine compositions for } \\
\text { onychomycosis treatment }\end{array}$ & E.Touitou & $\begin{array}{l}\text { W020100867 } \\
\text { 23A1 }\end{array}$ & 2010 & $\begin{array}{l}\text { Novel terbinafine topical } \\
\text { compositions for the treatment of } \\
\text { nail onychomycosis }\end{array}$ \\
\hline
\end{tabular}

\section{CONCLUSION}

Ethosomes are a pioneering platform technology that offers modified delivery systems to meet the necessary criteria for efficient and safe drug administration into and across the skin. Considerable research has been conducted to characterize this novel non-invasive carrier. Because of their composition, ethosomes are soft vesicles, which penetrate through the SC lipids and transport the active agent to the deep layers of the skin. These vesicular systems were proven efficient for dermal and transdermal delivery of various energetic agents in animals and humans. Among the many areas where ethosomal transdermal delivery could be helpful are Parkinson's disease, hormone replacement therapy, cardiovascular treatments and rheumatic disorders. Delivery of antibiotics and antiviral to the deep layers of the skin and drugs for management of alopecia to the hair follicles by an ethosomal carrier could greatly increase drug treatment competence and patient convenience. The highly competent delivery, together with its lack of toxicity and preparation simplicity, makes this system a promising candidate for the administration of chemical and biological compounds. Such developments may further increase the field of transdermal applications. 


\section{REFERENCES}

1. Schaefer H, Redelmeier TE. Skin Barrier Principles of Percutaneous Absorption. Basel: Karger AG, 1996.

2. Barry WB. Dermatological Formulations: Percutaneous Absorption. New York, Basel: Marcel Dekker, 1983.

3. Flynn GL. Cutaneous and transdermal delivery: processes and systems of delivery. In: Banker GS, Rhodes CT, editors. Modern Pharmaceutics. New York: Marcel Dekker, 1995.

4. Smith EW, Maibach HI. Percutaneous Penetration Enhancers. New York: CRS Press, 1995.

5. Elias PM. Epidermal lipids, barrier function and desquamation. J Invest Dermatol 1983; 80:44-9.

6. Pirot F, Kalia YN, Stinchcomb AL, et al. Characterization of the permeability barrier of human skin in vivo. Proc Natl Acad Sci USA 1997; 94:1562-7.

7. Barry B. Transdermal drug delivery. In: Aulton EM, eds. Pharmaceutics: the science of dosage form design. London: Churchill Livingstone, 2002; 499-528.

8. Barry B. Breaching the skin's barrier to drugs. Nat Biotechnol 2004; 22:165-7.

9. Honeywell NPL, Bouwstra JA. Vesicles as a tool for transdermal and dermal delivery. Drug Discov Today Technol 2005; 2:67-74.

10. Touitou, E., Godin, B and Weiss, C., Enhanced Delivery of Drug Into and Across The Skin By Ethosomal Carrier, Drug Develop. Res. 2000; 50:406-415.

11. Paolino D, Lucania G, Mardente D, Alhaique F, Fresta M. Ethosome For Skin Delivery of Ammonium Glycyrrhizinate: In Vitro Percutaneous Permeation Through Human Skin And In Vivo Anti Inflammatory Activity on Human Volunteers, J. Cont. Rel, 2005; 106:99- 110.

12. Jun-Bo T, Zhuang-Qun $\mathrm{Y}$, Xi-Jing $\mathrm{H}$, Ying $\mathrm{X}$, Yong S, Zhe X, Tao C. Effect Of Ethosomal Minoxidil on Dermal Delivery, J Dermatol Sci, 2007; 45:135-137.

13. Pandey V, Golhani D, Shukla R. Ethosomes: versatile vesicular carriers for efficient transdermal delivery of therapeutic agents. Drug Delivery, DOI: 10.3109/10717544.2014.889777.

14. Flynn G H. at el. Transdermal delivery of narcotic analgesics, Comparative permeabilities of narcotic analgesics through human cadaver skin, Pharm Res, 1989; 6:825-832.

15. Wertz P W, Downing D T; In Transdermal Drug Delivery, Development Issues and Research Initiatives, Hadgraft, J J, Guy R H. Eds. Marcel Dekker Inc, New York. 1989; 35:1-22.

16. Nandure HP, Puranik P, Giram P, LoneV. Ethosome: A Novel Drug Carrier. International Journal of Pharmaceutical Research \& Allied Sciences 2013; 2(3);18-30.

17. Elsayed Mustafa MA et al. Deformable liposomes and ethosomes: mechanism of enhanced skin delivery. Int J pharm 2006; 322:60-66.

18. Maestrelli F, Capasso G, Gonzalez-Rodriguez ML, Rabasco AM, Ghelardini C, Mura P. Effect of preparation technique on the properties and in vivo efficacy of benzocaine-loaded ethosomes. J Liposome Res. 2009; 19(4): 253260.

19. Rani S, David N, Pin CF. Formulation and invitro evaluation of ethosomeas vesicular carrier for enhanced topical delivery of isotretinoin, International Journal of Drug Delivery, 2013; 5:28-34.

20. Song CK, Balakrishnan P, Shim CK, Chung SJ, Chong S, Kim DD. A novel vesicular carrier, transethosome, for enhanced skin delivery of voriconazole: characterization and in vitro/in vivo evaluation. Colloids Surf B Biointerfaces. 2012; 92:299-304.

21. Zhang JP, Wei YH, Zhou Y, Li YQ, Wu XA. Ethosomes, binary ethosomes and transfersomes of terbinafine hydrochloride: a comparative study. Arch Pharm Res. 2012; 35(1):109-117.

22. Dave V, Kumar D, Lewis S, Paliwal S. Ethosome for enhanced transdermal drug delivery of aceclofenac. Int J Drug Deliv. 2010; 2(1):81-92.

23. Gangwar S, Singh S, Garg G. Ethosomes: A Novel Tool for Drug Delivery Through the Skin, Journal of Pharmacy Research 2010; 3(4):688-691.

24. Jain H, Patel J, Joshi K, Patel P, Upadhyay UM. Ethosomes: A Novel Drug Carrier, International Journal of Clinical Practice 2011; 7:1:1-4.
25. Upadhyay N, Mandal S, Bhatia L, Shailesh S, Chauhan P. A Review on Ethosomes: An Emerging Approach for Drug Delivery through the Skin, Recent Research in Science and Technology 2011; 3(7):19-24.

26. Sivakranth M, AnjumaAra P, Krishnaveni C, Venkatesh E. Ethosomes: A Novel Vesicular Drug Delivery System, International Journal of Advances in Pharmaceutical Research 2012; 2(1):16-27.

27. Kumar R, Aslam MD, Tripathi A, Prasad D, Chaudhary V, Jain V, Mishra SK, Singh R. Ethosomes: Novel Vesicular Carriers in Transdermal Drug Delivery, Journal of Global Pharma Technology 2010; 2(6):1-7.

28. Rathore AR, Khambete H, Jain S. Preparation and Characterization of Repaglinide Loaded Ethosomal Gel for the Treatment of NIDDM, International Journal of Pharmaceutical and Biological Archives 2013; 4(2):385-390.

29. Shahwal V, Samnani A, Dubey B, Bhowmick M. Ethosomes: An Overview, International Journal of Biomedical and Advance Research 2011; 2:161-168.

30. Kumar R, Aslam M.D, Tripathi A, Prasad D, Chaudhary V, Jain V, Mishra S K, Singh R. Ethosomes novel vesicular carriers in transdermal drug delivery. J Global Pharma Tech 2010; 2(6):17.

31. Heeremans JLM, Gerristen HR, Meusen SP, Mijnheer FW, Gangaram RS, Panday G, Prevost R, Kluft C, Crommelin DJA. The preparation of Tissue Type Plasminogen Activator (T- PA) containing liposomes: Entrapment Efficacy and Ultracentrifugation Damage, Journal of Drug Targeting 1995; 3:301.

32. Jain S, Umamaheshwari RB, Bhadra D, Jain NK. Ethosomes: A Novel Vesicular Carrier for Enhanced Transdermal Delivery of a Anti-HIV Agent, Indian Journal of Pharmaceutical Sciences 2004; 66:72-81.

33. Verma DD, Fahr A, Synergistic Penetration Effect of Ethanol and Phospholipids on the Topical Delivery of Cyclosporin, Journal of Controlled Release 2010; 97:55-66.

34. Touitou E. Composition of Applying Active Substance to or Through the Skin, US patent: 5, 540, 934, 1998.

35. Touitou E, Composition of Applying Active Substance to or Through The Skin, US patent: 5, 716, 638, 1996.

36. Tyagi LK, Kumar S, Maurya SS, Kori ML. Ethosomes novel vesicular carier for enhanced transdermal drug delivery system. Bulletin Pharm Res 2013; 3(1):6-13.

37. Dhurve R, Kashyap N, Mishra A, Pathak AK. A Holistic Review on Ethosome: A Promising Drug Delivery System for Topical Fungal Disease International Journal of Pharmaceutical \& Biological Archives 2014; 5(5):13-26

38. Ghule AR, Shinkar DM, Saudagar RB. Ethosomes: Carrier for Enhanced Transdermal Drug Delivery System, J. Adv. Pharm. Edu. \& Res. 2014; 4(4):380-387

39. Sudhakar K, Nitish U, Sanjay J R, Narayana C. Ethosomes as non-invasive Loom for transdermal drug delivery. Apple Academic Press Publication. 2012.

40. Maurya SD, Prajapati SK, Gupta AK Saxena GK, Dhakar RC, Formulation Development and Evaluation of Ethosome of Stavudine, Indian J.Pharm. Educ. Res. 2010; 44(1):102-108

41. Gangwar S, Ethosomes: For Drug Delivery, Journal of Pharmacy Research 2010; 3(4):688-691.

42. Kumar KP, Radhika PR, Sivakumar T. Ethosomes: A Priority in Transdermal Drug Delivery, International Journal of Advances in Pharmaceutical Sciences 2010; 1:111-121.

43. Touitou E at al., Composition of Applying Active Substance To or Through The Skin, US Patent: 5716638, 1996.

44. Touitou E at al., Composition of Applying Active Substance To or Through the Skin. US Patent: 5540934, 1998.

45. Mohanty D, Babu MN, Ankitha K, Gunde S, Bakshi V, Jat RM. Ethosome: a recent optimized technology for transdermal drug penetration, European Journal of Biomedical AND Pharmaceutical sciences 2016; 3(12):232-240. 